Canadian University Music Review

Revue de musique des universités canadiennes

\title{
Gayle Young. The Sackbut Blues: Hugh Le Caine, Pioneer in Electronic Music. Ottawa: National Museum of Science and Technology, 1989. xiv, 274 pp. ISBN 0-660- 12006-2
}

\section{David Keane}

Volume 11, numéro 1, 1991

URI : https://id.erudit.org/iderudit/1014834ar

DOI : https://doi.org/10.7202/1014834ar

Aller au sommaire du numéro

Éditeur(s)

Canadian University Music Society / Société de musique des universités canadiennes

ISSN

0710-0353 (imprimé)

2291-2436 (numérique)

Découvrir la revue

Citer ce compte rendu

Keane, D. (1991). Compte rendu de [Gayle Young. The Sackbut Blues: Hugh Le Caine, Pioneer in Electronic Music. Ottawa: National Museum of Science and Technology, 1989. xiv, 274 pp. ISBN 0-660- 12006-2]. Canadian University Music Review / Revue de musique des universités canadiennes, 11(1), 128-131. https://doi.org/10.7202/1014834ar

All Rights Reserved (c Canadian University Music Society / Société de musique des universités canadiennes, 1991
Ce document est protégé par la loi sur le droit d'auteur. L’utilisation des services d'Érudit (y compris la reproduction) est assujettie à sa politique d'utilisation que vous pouvez consulter en ligne.

https://apropos.erudit.org/fr/usagers/politique-dutilisation/ 


\section{REVIEWS/COMPTES RENDUS}

GAYLE YOUNG. The Sackbut Blues: Hugh Le Caine, Pioneer in Electronic Music. Ottawa: National Museum of Science and Technology, 1989. xiv, 274 pp. ISBN 0-66012006-2

Canada has a history of original and creative thinkers, and Hugh Le Caine (1914-1977) must be one of the most remarkable among them. LeCaine was both an experimenter and an inventor. In the 1920's, he experimented with aspects of sound recording and processing; John Cage did much the same things in the late 1940's and early 1950's and almost immediately became a celebrity. In the 1940's, Le Caine designed and built a musical synthesizer (described in The New Grove Dictionary of Musical Instruments as "the earliest instrument that resembles a synthesizer" [Davies 1984: 680], whose power and flexibility of control still has not been surpassed by modern digital instruments; Robert Moog built a similar instrument twenty years later and gained no small reputation thereby.

While still a child, Le Caine built such futuristic, if rather impractical, devices as an electronic ukulele, a paper-roll-driven autoharp, and a guitar with foot pedals for tuning like those of a harp. He experimented with processing sounds by means of microphones and speakers and by means of modified playback of homemade phonograph recordings. His absolute pitch, remarkable musical memory, and formal and autodidactic study of musical instruments made him particularly suited to musical instrument invention. After the first synthesizer, he went on to create the first polyphonic synthesizer, an audio playback device that allowed for highly controlled mixing and editing, and ingenious controllers to allow composers to interact with synthesizers and tape recorders.

Given his unusual accomplishments, perhaps the most remarkable aspect of the man was his shyness. Although he was the composer of the first (and for many years, the most famous) tape composition produced in Canada and for more than a decade the Canadian composer of electroacoustic music best represented on disc, he never considered himself a real composer. He maintained he was only trying out his instruments to see them from the composer's point of view. He tried in various ways to draw the attention of composers to what his instruments had to offer, but the attempts were so humble that few composers or performers came to know of Le Caine's accomplishments during his lifetime.

There were illustrious moments, of course. Arnold Walter seized upon Le Caine's work and, in cooperation with the National Research Council (Le Caine's lifelong employer), set up the University of Toronto Electronic Music Studios (UTEMS). In 1959, this was but the second electronic music studio in North America (the Columbia-Princeton Electronic Music Center having been established the preceding year) and for the next ten years one of the of the world's most important centres for the art. Le Caine filled UTEMS with his marvellous devices and, a few years later, did the same for Istvan Anhalt's facility at McGill University. He also placed equipment in the studios of the Hebrew University of Jerusalem and Queen's University (Le Caine's alma mater, where the School of Music building was named, in part, in his honour in 1974).

Le Caine published much of his work in technical journals and occasionally in musical ones, but the world was not quite ready at that time to make much use of such information. 
Moreover, since Le Caine worked for the Canadian National Research Council, the marketing of his inventions was subject to certain restrictions. Perhaps more importantly, even where commercial production of Le Caine's devices seemed to be on the horizon, his modesty and perfectionism made him reluctant to agree that a project was finally ready for manufacture. Robert Moog's name became synonymous with musical synthesizers for more than a decade not because he made a better synthesizer but because he managed actually to market one (something perhaps easier to accomplish in the United States).

By the time of Le Caine's death in 1977 as the result of a motorcycle accident (motorcycling at 61 - I said he was remarkable), the concept of both synthesizer and tape music had come of age. Canada was and remains one of the clear leaders in the field, and that leadership is owing in large part directly and indirectly to Le Caine's industry and imagination. Even so, Le Caine himself was little known among people taking up work in the field and quite unknown to the general public.

Le Caine had a distinctive, even eccentric, personality as well as a considerable degree of a rough sort of charm. Those who actually knew him would certainly never forget him or his accomplishments. In the year following Le Caine's death, there seems to have been an increasing awareness that someone very special had passed out of this world. Shortly thereafter, efforts were made to mark his accomplishments. Several compositions were created in Le Caine's memory, and a very well attended memorial concert was organized at Queen's University which drew many colleagues and admirers from Ottawa, Toronto, and Montréal. Also, it was at this time that the "Hugh Le Caine Project" came into being. It was undertaken by James Montgomery and Larry Lake, composers who had worked with Le Caine at UTEMS, and their administrative assistant, Gayle Young, a recent graduate of the music program at York University.

The "Hugh Le Caine Project" set out to document and preserve what Le Caine had left in his wake: writings, recordings, and instruments. A number of brief but quite informative newsletters came out of the project and indicated that the scattered instruments had been located, photographed, and studied. Over the years the work continued steadily, but more and more became the project of one dedicated person, Gayle Young. Ms. Young had dabbled in electroacoustic music, but she had never met Le Caine. What seems to have drawn her to Le Caine's work, besides its own remarkable qualities, is the fact that she, too, is an inventor of instruments, a player upon those instruments, and a composer of music for them. Young's instruments are acoustic rather than electronic ones, but there seems in this to be an important bond between her and Le Caine's heritage nonetheless.

In the decade or so that followed Le Caine's death, Young made herself an expert on every aspect of Le Caine's life and work. Following the series of newsletters, she produced an LP album (JWD Music, 1985) documenting the compositions and the instruments as well as offering an insight into Le Caine's personality through the brief, spoken introductions taken for demonstration tapes made by Le Caine over the years. At this same time, Young was instrumental in bringing a number of Le Caine's devices together in the National Museum of Science and Technology. One of the primary aims of the original "Hugh Le Caine Project" was to see the instruments restored and made available for exhibition and even use. Thus far, the devices are only under the museum's protection, but it is hoped that restoration and display may be possible in the near future.

Young's most recent and most significant undertaking has been to bring her book on Le Caine to completion. Probably the most important source for the book was Le Caine's own 
unpublished manuscript, "Recherches au Temps Perdu: Some Personal Recollections of My Work in Electronic Music Written at the Request of a [Music] History Student, Queen's University," written in 1966 and containing a rambling account of events and of Le Caine's thoughts about the course of his career. Young has also sought to obtain personal insights from family, friends, and colleagues. She has also made her way through extensive archives of tapes, photographs, papers, and other documents at the National Research Council and at the home of Le Caine's widow to present a comprehensive picture of Le Caine's life and work.

The Sackbut Blues presents very well the complicated circumstances in which Le Caine nurtured and developed his interests in music technology. While Young does not editorialize but simply reports to the reader what she has learned, there is sufficient information for the reader to draw conclusions on his or her own. For example, it is almost as though Le Caine not only weathered public indifference to his work but also became oddly accustomed to it. In his final years before retirement in 1974, with universities across Canada becoming increasingly interested in his work, he actually seemed to become less and less impassioned and simply to manufacture whatever was asked for. He reacted rather than initiated as he had done for most of his life. The Sackbut Blues does not so much say this as it allows the reader to infer it in following Young's account of Le Caine's career.

The Sackbut Blues contains about 170 pages of biography interspersed with some analysis of Le Caine's compositions. The remainder of the book is devoted to systematic explanation of each of Le Caine's instruments and includes many excellent diagrams and photographs. There is also a thorough bibliography and a useful set of notes. Despite the often rather technical nature of Le Caine's work, this book makes quite engaging and easily digestible reading for the lay person. The fact that Young is not herself a technologist is possibly a factor in her achieving this accessible style. Moreover, it is perhaps an advantage that Young was not acquainted with Le Caine in that her perspective has thus become a comfortable composite of those of the many people she interviewed. (It should be noted here that views of the man are not particularly divergent: one thing that is very clear is that anyone who knew Hugh Le Caine had unbounded respect for him.)

Given that Le Caine was an extremely interesting and unusual personality (shy, nocturnal, obsessive in seeking answers to questions, and with a penchant for turning his living quarters into laboratories), a visionary and inventor working on the frontiers of audio technology and musical ergonomics, and a serious music composer of wit and imagination - not to mention a nuclear physicist, and experimental photographer, and a dedicated "biker," a book on Le Caine might have been one of many books. What may be the best aspect of The Sackbut Blues is that while the reader is given a substantial glimpse into each of these areas, the book is quite brief and to the point. Young offers us a warm human story, an important piece of Canadian musical and technological history, and a valuable reference book in the bargain.

As for the title, The Sackbut Blues refers to an engaging and amusing composition that Le Caine created for piano and his 1945 synthesizer which he dubbed the "Sackbut." (He had already come to appreciate what is particularly obvious today: new devices are obsolete almost as soon as they appear. He thought it appropriate, then, to name his instrument after another obsolete one.) He pointed out that he intended the composition to have a mood that might be characterized as "low-down." He added, "I believe you will agree that a new 
peak in 'low-downness' has been achieved." The tale told in Gayle Young's book is a generally positive one, but there is a lingering melancholy for what the reader cannot help imagining might have been that makes this echoing of Le Caine's title not at all inappropriate.

David Keane

\section{REFERENCES}

DAVIES, Hugh.

1984: "Electronic Instruments," The New Grove Dictionary of Musical Instruments, ed. S. Sadie. New York: Grove Dictionaries of Music.

JWD Music.

1985: Hugh Le Caine: Pioneer in Electronic Music Instrument Design; Compositions and Demonstrations, 1948-1972. Grimsby, Ont.: JWD Music/Hugh Le Caine Project. [Available from JWD Music, 146 Ridge Road West, Grimsby, Ontario, L3M 4E7.]

DAVID P. SCHROEDER. Haydn and the Enlightenment: the Late Symphonies and their Audience. Oxford: Clarendon Press, 1990. vii, 219 pp. ISBN 0-19-816159

Despite some recent attempts to extend the scope of traditional musicology, most books on Classic period music continue to follow the familiar "positivist" line and approach the relatively uncharted waters of cultural and social history gingerly and with undisguised caution. The reasons for this are not difficult to find: the very language and terms still customarily used to discuss such fundamental musical issues as form, thematic development, and harmonic analysis were developed initially in conjunction with efforts to describe the morphology of Classic period music; and the mental patterns this has established, it seems, have tended to discourage forays beyond the prevailing boundaries of positivist historical and analytical discourse.

In this sense, David Schroeder's book pursues a new tack. Starting with a broad, allencompassing premise, Schroeder attempts to marry the language and concerns of social and intellectual history with those of stylistic and formal analysis - in effect, to explain the Zeitgeist of the Enlightenment in musical terms. Whereas most studies that focus on intellectual and social history tend to treat the actual music from a distance and to discuss individual works only in the most general terms, Schroeder tries valiantly to merge these two fundamentally antithetical casts of mind. Using the language of a "close reading" of individual scores - analysis, in other words - Schroeder argues points that lie ultimately in the realm of intellectual history and reception history. Since such attempts are rare (in music at least), and since there is no established tradition of what constitutes satisfactory proof, the success or failure of Schroeder's thesis depends very much upon the intellectual predilections of the individual reader and upon whether that reader can be persuaded by the nature of the arguments. Can, for example, the character and development of a given theme, or even the structural properties of an entire movement or work, serve as evidence concerning Haydn's mental outlook and his effort to improve "public morality"? Or, to 